\title{
Regeneration of Active Surface Alloys during Cyclic Oxidation and Reduction: Oxidation of $\mathrm{H}_{2}$ on $\mathrm{Pd} / \mathrm{Ag}(111)$
}

Supporting Information

Tobias Egle, ${ }^{1}$ Christopher R. O'Connor, ${ }^{2}$ Cynthia M. Friend ${ }^{1,2, *}$

${ }^{1}$ School of Engineering and Applied Sciences, Harvard University, Cambridge, MA 02138, USA

${ }^{2}$ Department of Chemistry and Chemical Biology, Harvard University, Cambridge, MA 02138, USA

Corresponding author

*friend@fas.harvard.edu 


\section{$\mathrm{X}$-ray photoelectron data for $\mathrm{C} 1 \mathrm{~s}$ and $\mathrm{O}$ 1s regions:}

The $\mathrm{O} 1 \mathrm{~s}$ and $\mathrm{C} 1 \mathrm{~s}$ X-ray photoelectron spectra (Figures S1, S2) obtained in the experiments used to generate Figures 1 and 2 of the main text establish that there is negligible carbon buildup in our experiments. These data rule out the possibility that carbonate accumulates in our experiments. Notably, great care was taken in our experiments to minimize background $\mathrm{CO}$ through repeated baking of the ambient-pressure cell in an $\mathrm{O}_{2}$ environment. The $\mathrm{C} 1 \mathrm{~s}$ and $\mathrm{O}$ 1s data were not fit because of the low signal intensities rendering quantitative analysis of the data prone to large errors. The upper bound on the amount of carbon accumulated from the background is $0.08 \mathrm{ML}$, based on the relative intensity of the $\mathrm{C} 1 \mathrm{~s}$ region compared to the $\mathrm{Pd} 3 \mathrm{~d}_{5 / 2}$ data in Figure 1.

Qualitatively, the peak at $\sim 532 \mathrm{eV}$ after initial Pd deposition is attributed to the $\mathrm{Pd} 3 \mathrm{p}_{3 / 2}$ signal from metallic Pd. Upon oxidation, the Pd $3 \mathrm{p}_{3 / 2}$ shifts to higher binding energy similar measurements for $\mathrm{PdO}_{\mathrm{x}}{ }^{1}$ (Figure S1). After oxidation, $\mathrm{O} 1 \mathrm{~s}$ peaks at $\sim 530$ and $\sim 528 \mathrm{eV}$ are observed. The peak at $\sim 530 \mathrm{eV}$ is attributed to a combination of adsorbed $\mathrm{OH}$ and oxygen bound to $\mathrm{Pd}$, whereas the peak near $528 \mathrm{eV}$ is attributed to oxygen bound to Ag. There may be a minimal amount of carbonate contributing to the peak around $530 \mathrm{eV}$. For reference, the $\mathrm{O} 1 \mathrm{~s}$ binding energies of various species on $\mathrm{Pd}$ and $\mathrm{Ag}$ are summarized (Table S1).

Table S1. O 1s and $\mathrm{Pd} 3 \mathrm{p}_{3 / 2}$ binding energies

\begin{tabular}{l|c|c|c|c|}
\hline Surface & Region & Species & $\begin{array}{c}\text { Binding Energy } \\
(\mathbf{e V})\end{array}$ & References \\
\hline $\mathrm{Pd}(111)$ & $\mathrm{Pd} \mathrm{3}_{3 / 2}$ & Pd-metallic & $\sim 532.0$ & $2-4$ \\
\hline $\mathrm{Pd}(111)$ & $\mathrm{Pd} 3 \mathrm{p}^{3 / 2}$ & Pd-oxide & $\sim 533.0$ & $2-5$ \\
\hline $\mathrm{Pd}(111)$ & $\mathrm{O} 1 \mathrm{~s}$ & 3-fold coordinated oxygen & $\sim 528.5$ & $2-6$ \\
\hline $\mathrm{Pd}(111)$ & $\mathrm{O} 1 \mathrm{~s}$ & 4-fold coordinated oxygen & $\sim 529.6$ & $2-6$ \\
\hline $\operatorname{Ag}(111) / \mathrm{Pd}(111)$ & $\mathrm{O} 1 \mathrm{~s}$ & $\mathrm{OH}$ & $\sim 531.5-532.0$ & $6-8$ \\
\hline $\operatorname{Ag}(111)$ & $\mathrm{O} 1 \mathrm{~s}$ & carbonate & $\sim 530.0-531.0$ & $7,9-11$ \\
\hline $\operatorname{Ag}(111)$ & $\mathrm{O} 1 \mathrm{~s}$ & $\mathrm{O}$ ads & $\sim 530.2$ & $7,10,11$ \\
\hline $\operatorname{Ag}(111)$ & $\mathrm{O} 1 \mathrm{~s}$ & $\mathrm{AgO}$ & $\sim 529.0$ & $7,10,11$ \\
\hline $\operatorname{Ag}(111)$ & $\mathrm{O} 1 \mathrm{~s}$ & $\mathrm{p}(4 \times 4)-\mathrm{O}$ & $\sim 528.3$ & $7,12,13$ \\
\hline
\end{tabular}



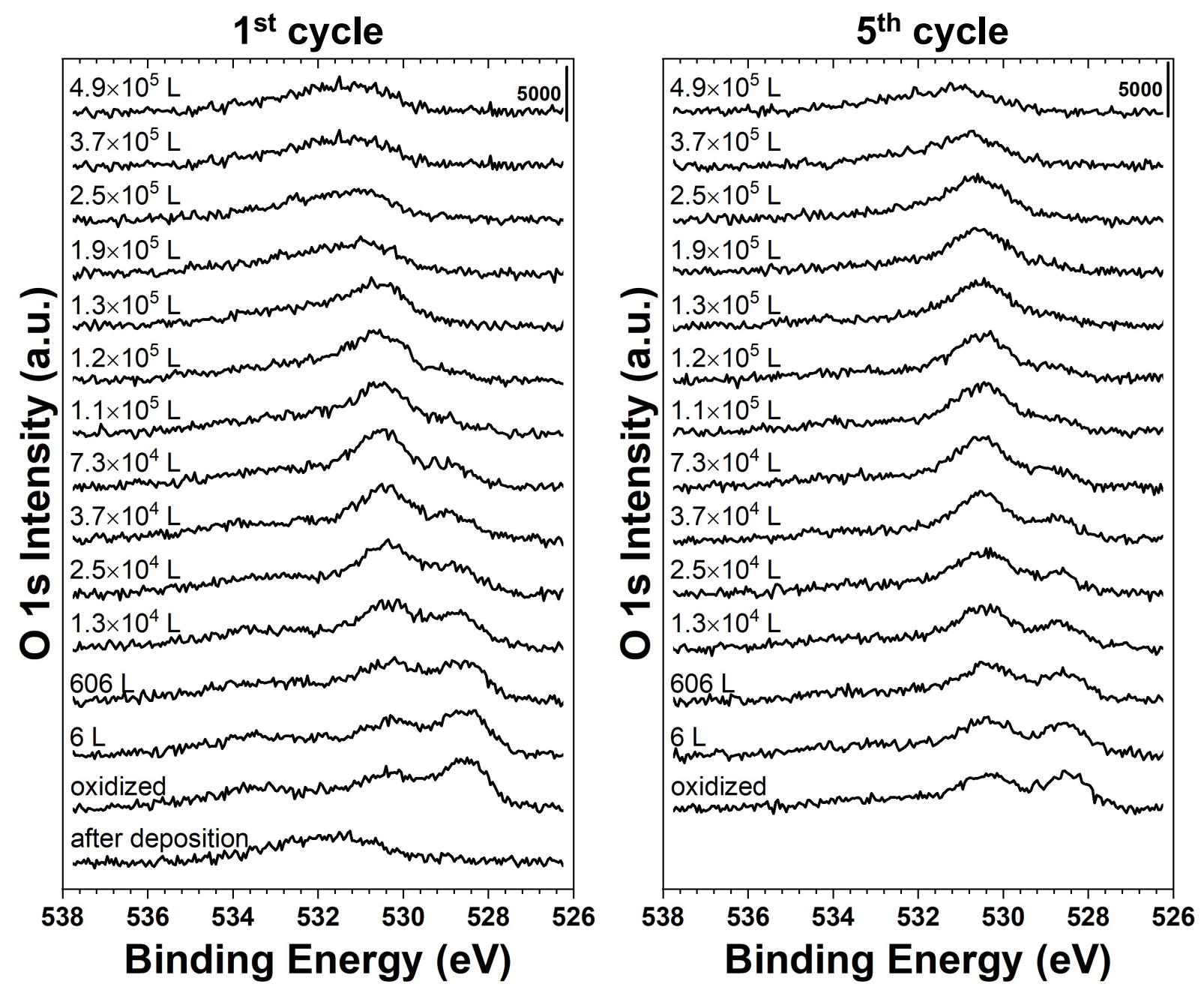

Figure S1. Oxygen 1s X-ray photoelectron spectra corresponding to the data shown in Figures 1 and 2 of the main text for the first (left) and the fifth (right) cycles of oxidation and reduction. The data shown from bottom to top show the change in the $\mathrm{O} 1 \mathrm{~s}$ region after oxidation and cumulative $\mathrm{H}_{2}$ exposure. The data were collected at an emission angle of 65 degrees with respect to the sample normal to reach a probing depth of $\sim 1.7 \mathrm{~nm}$. Note the Pd3p for reduced $\mathrm{Pd}(\sim 532 \mathrm{eV})$ and oxidized $\mathrm{Pd}(\sim 533 \mathrm{eV})$ shifts, where further assignments are in Table $\mathrm{S} 1$. 
$1^{\text {st }}$ cycle

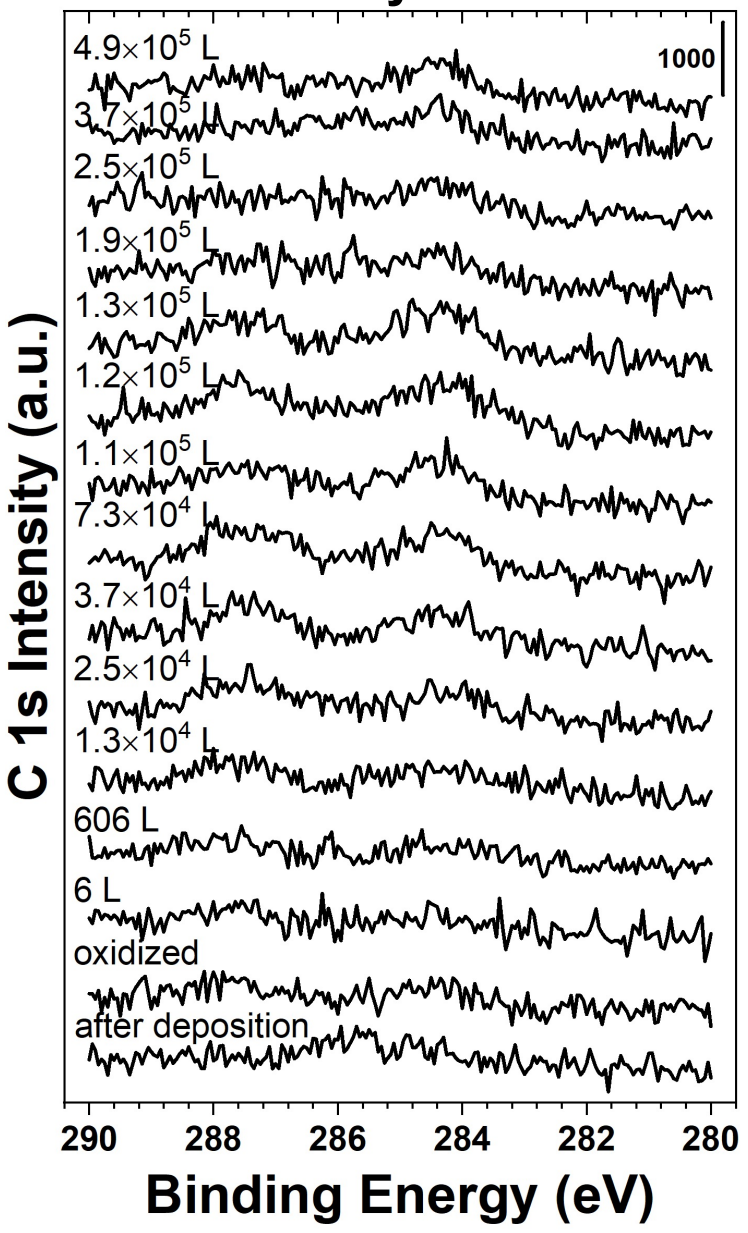

$5^{\text {th }}$ cycle

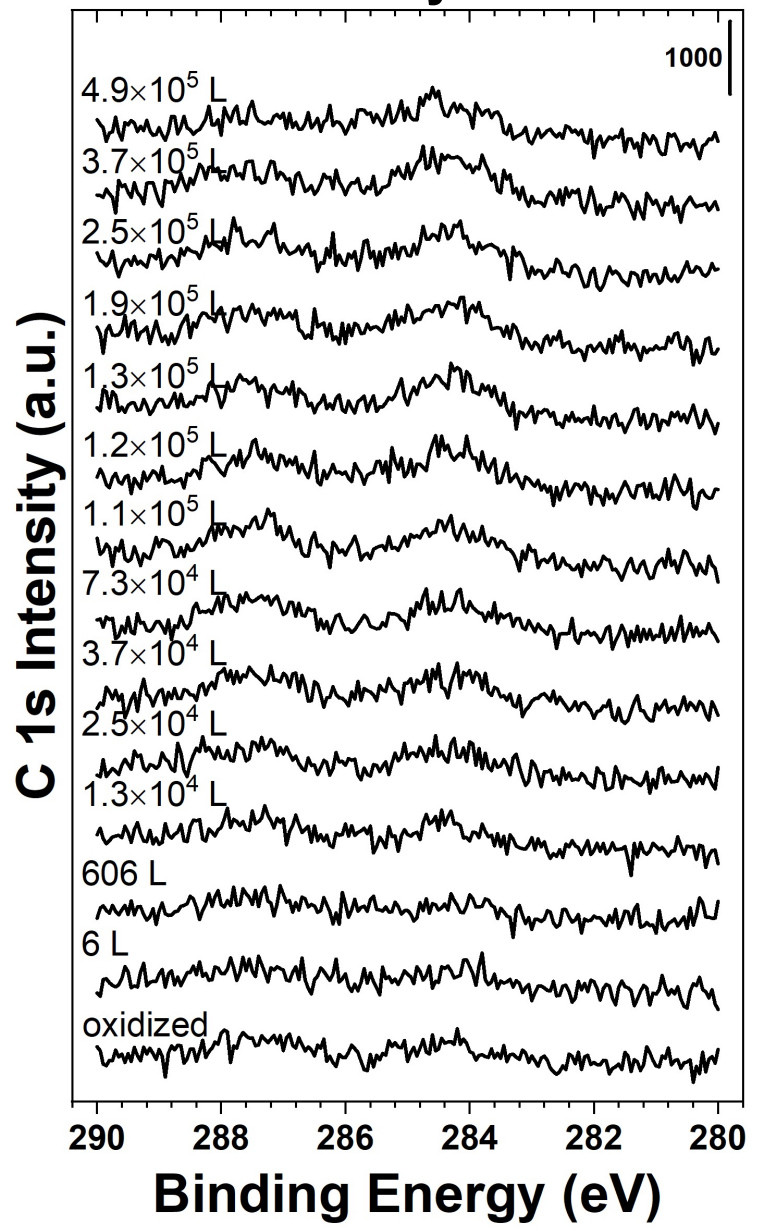

Figure S2. Carbon 1s X-ray photoelectron spectra corresponding to data in Figures 1 and 2 of the main text for first (left) and fifth (right) cycles of oxidation and reduction. The data shown from bottom to top show the change in the $\mathrm{C} 1 \mathrm{~s}$ region after oxidation and cumulative $\mathrm{H}_{2}$ exposure. The data were collected at an emission angle of 65 degrees with respect to the sample normal to reach a probing depth of $\sim 1.7 \mathrm{~nm}$. 


\section{$\mathrm{X}$-ray photoelectron data for $\mathrm{Pd} 3 \mathrm{~d}_{5 / 2}$ and $\mathrm{Ag} 3 \mathrm{~d}_{5 / 2}$ regions:}

A complete set of data for the $\mathrm{Pd} 3 \mathrm{~d}_{5 / 2}$ and $\mathrm{Ag} 3 \mathrm{~d}_{5 / 2}$ regions shows the changes in peak intensities upon oxidation and reduction (Figures S3, S4). The color coding of the peaks is the same as the main text. In the $\mathrm{Pd} 3 \mathrm{~d} 5 / 2$ region, green corresponds to metallic $\mathrm{Pd}$ and red signifies oxidized Pd. The grey peaks in the is $\mathrm{Ag} 3 \mathrm{~d}_{5 / 2}$ region is due to metallic $\mathrm{Ag}$ and the green attributed to PdAg alloy.

The probe depth was estimated using the analysis (take-off) angle of $\theta=65$ degrees to calculate the inelastic mean free path (IMFP) of $\mathrm{Ag} 3 \mathrm{~d}$ photoelectrons ${ }^{14}$ through silver: $\lambda_{\theta}=$ $\lambda_{\text {normal }} \cos (\theta)=1.305 \mathrm{~nm} \cdot \cos \left(65^{\circ}\right)=0.55 \mathrm{~nm}$ for a beam energy of $1253.6 \mathrm{eV}(\mathrm{Mg} \mathrm{K} \alpha$

anode) are used. The IMFP correlates to $\frac{0.55 \mathrm{~nm}}{0.41 \mathrm{~nm} * \frac{\sqrt{3}}{3}} \frac{1}{\cos \left(65^{\circ}\right)}=5.5$ layers of metallic silver. The probing depth (95\% of signal) is $3 \lambda_{\theta}=1.67 \mathrm{~nm}$.

The ratio of the $\mathrm{Pd} 3 \mathrm{~d}_{5 / 2}$ to $\mathrm{Ag} 3 \mathrm{~d}_{5 / 2}$ peak intensities after Pd deposition can be easily quantified since single-layer Pd islands are formed when $\mathrm{Pd}$ is deposited at low flux $(<0.2$ $\mathrm{ML} / \mathrm{min}$ ) at room temperature. ${ }^{15}$ The ratio stabilizes after the third cycle after gradually falling. A drop in the ratio means that a fraction of the Pd dissolves into the bulk, leading to an attenuation of the $\mathrm{Pd} 3 \mathrm{~d}$ photoelectrons. The precise fraction of $\mathrm{Pd}$ atoms that remain on the surface is challenging to determine since XPS averages over $7.4 \mathrm{~mm}^{2}$ and $1.67 \mathrm{~nm}$ into the sample for these experiments. It is likely that the concentration of $\mathrm{Pd}$ varies layer-by-layer. Another quantity derived from XPS, the normalized $\mathrm{Pd}_{\mathrm{x}} \mathrm{Ag}_{1-\mathrm{x}}$ alloy intensity (Figure 3), increases from $\mathrm{Pd}$ deposition until the third cycle. The $\operatorname{Pd}_{\mathrm{x}} \mathrm{Ag}_{1-\mathrm{x}}$ alloy intensity was normalized with respect to the as-deposited sample $\left(\right.$ Normalized intensity $\left.=\frac{\text { Intensity after cycle } x}{\text { Intensity after Pd deposition }}\right)$. The alloy intensity is consistent with the $\mathrm{Pd} 3 \mathrm{~d}_{5 / 2}$ to $\mathrm{Ag} 3 \mathrm{~d}_{5 / 2}$ ratio and adds additional information about the average coordination of a $\mathrm{Pd}$ to an $\mathrm{Ag}$ atom. The binding energy of the $\operatorname{Pd}_{\mathrm{x}} \mathrm{Ag}_{1-\mathrm{x}}$ alloy peak has been determined in a separate experiment via angle-resolved XPS (Figure S7, Table S7) and confirmed via difference spectra for the $\mathrm{Ag} 3 \mathrm{~d}_{5 / 2}$ spectral region in this specific study (Figure 1C). The obtained fits show a consistent core-level shift of about $-0.3 \mathrm{eV}$ with respect to metallic silver. Pd-Ag alloy formation, indicating rearrangement at the interface, has been observed for a single cycle for the reduction of oxidized $\mathrm{Pd} / \operatorname{Ag}(111)$ by hydrogen before. ${ }^{16}$ The rearrangement was further confirmed by STM. 
Table S2. Peak fitting parameters for XP spectra in Figures 1, S3, S4, and S5.

\begin{tabular}{l|c|c|c|c|c|}
\hline & Metallic Pd & Pd oxide & Metallic Ag & Ag oxide & PdAg alloy \\
\hline Binding energy [eV] & $335.1 \pm 0.1$ & $336.4 \pm 0.1$ & $368.2 \pm 0.1$ & $367.7 \pm 0.1$ & $368.0 \pm 0.1$ \\
\hline FWHM [eV] & 1.15 & 1.3 & 0.85 & 0.89 & 0.90 \\
\hline Asymmetry Index & 0.058 & 0 & 0 & 0 & 0 \\
\hline
\end{tabular}
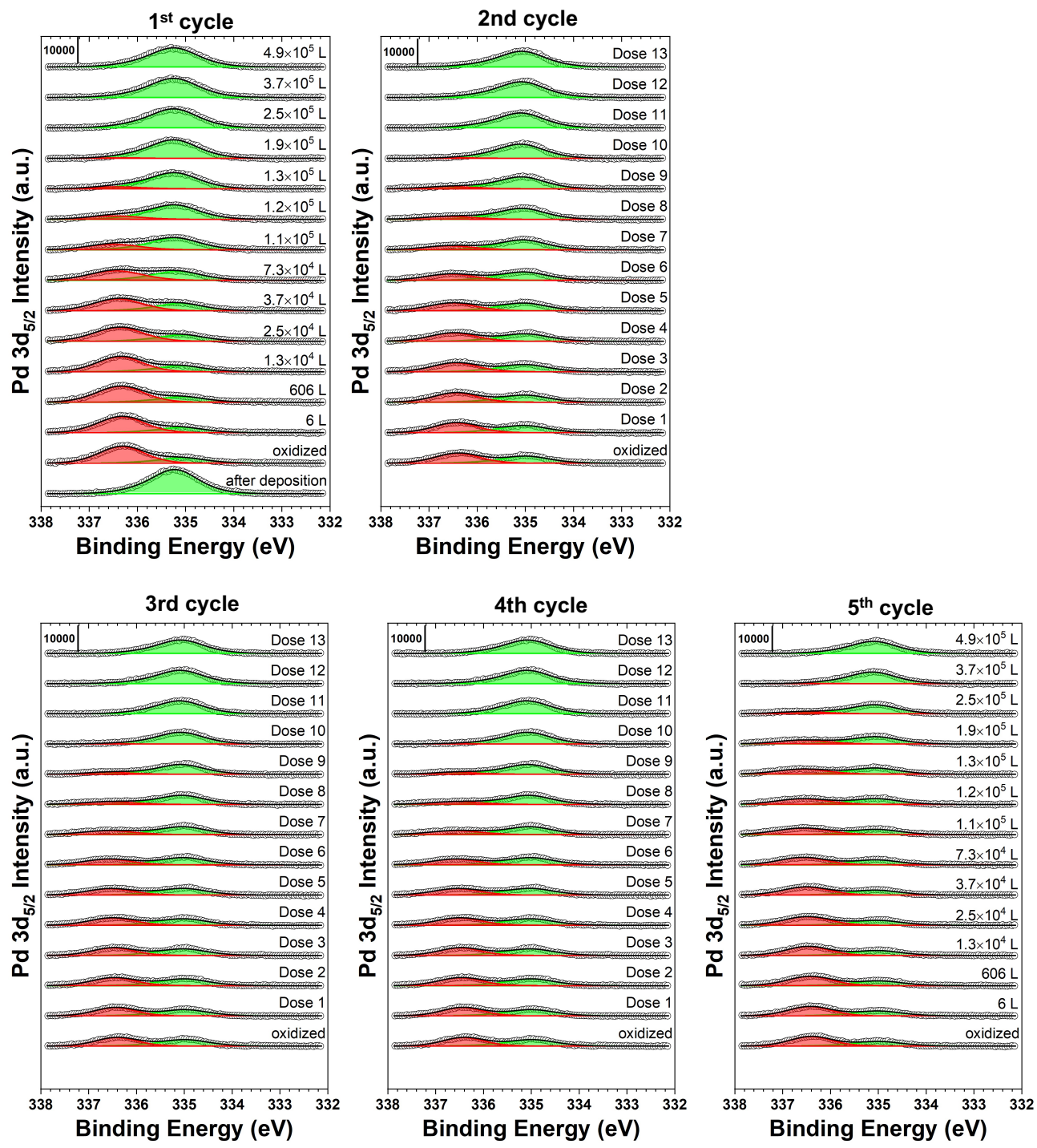

Figure S3. X-ray photoelectron spectra for the Pd $3 \mathrm{~d}_{5 / 2}$ region that were for the analysis shown in Figures 1 and 2 of the main text. Peaks shaded in green are metallic Pd and red due to oxidized Pd. The data shown from bottom to top in each panel show the change after oxidation and cumulative $\mathrm{H}_{2}$ exposure. The data were collected at an emission angle of 65 degrees with respect to the sample normal, yielding a probe depth of $\sim 1.7 \mathrm{~nm}$. Peak fitting parameters are given in Table S2 and the hydrogen does in Table S3. 

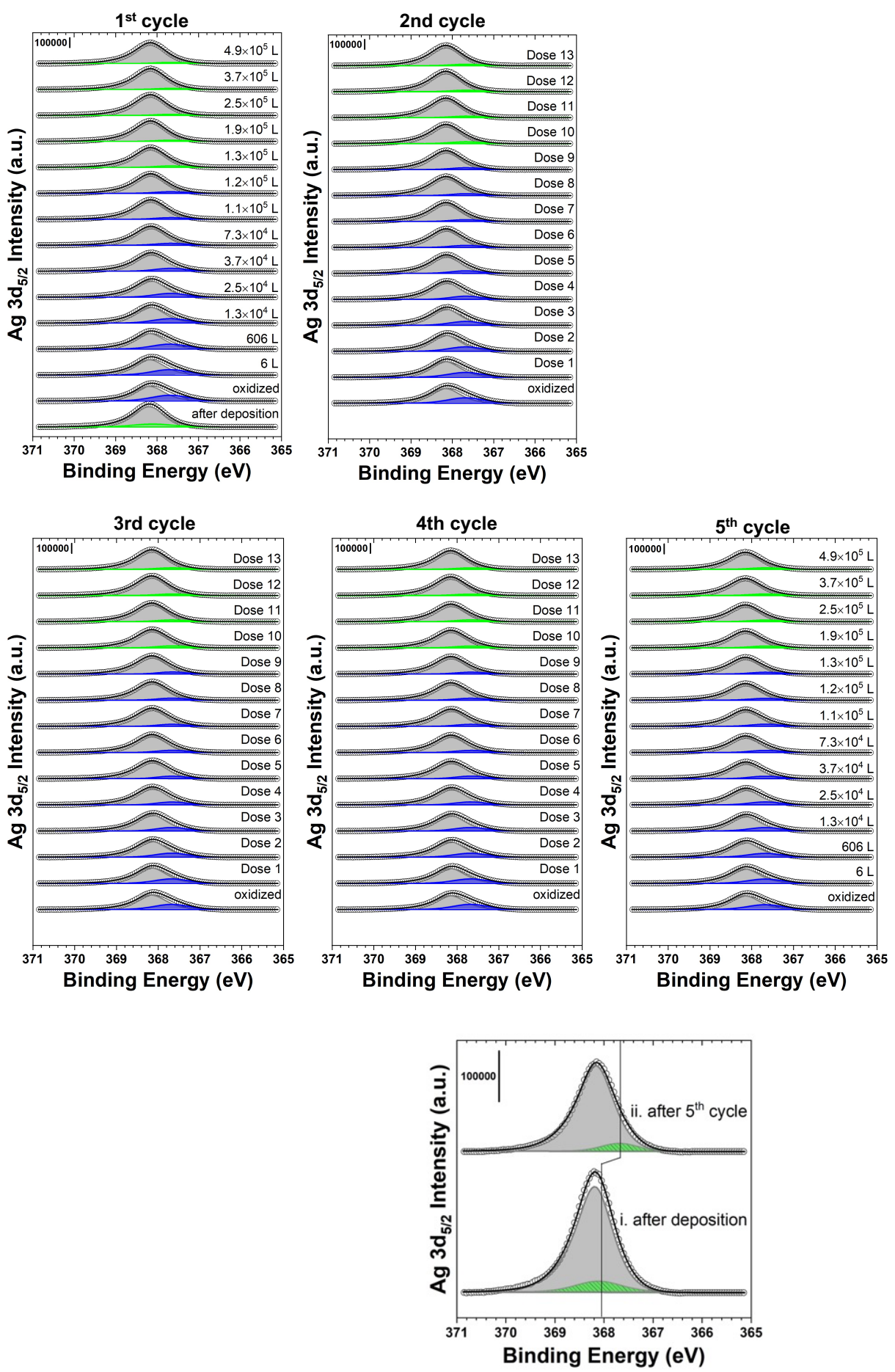

Figure S4. X-ray photoelectron spectra for the $\mathrm{Ag} 3 \mathrm{~d}_{5 / 2}$ region that were for the analysis shown in Figures 1 and 2 of the main text. Peaks shaded in grey are metallic Ag, in blue oxidized Ag and green the Pd-Ag alloy. The data shown from bottom to top in each panel show the change after oxidation and cumulative $\mathrm{H}_{2}$ exposure. The data in the bottom panel enlarge the energy scale to illustrate the change due to alloying between the initial deposition and the fifth cycle of oxidation/reduction. The data were collected at an emission angle of 65 degrees with respect to the sample normal, yielding a probe depth of $\sim 1.7 \mathrm{~nm}$. Peak fitting parameters are given in Table S2 and the hydrogen does in Table S3. 
Table S3. Hydrogen doses corresponding to data in Figures 2, S1 - S4.

\begin{tabular}{l|ccc}
$\begin{array}{l}\text { Dose } \\
\text { Number }\end{array}$ & $\begin{array}{c}\text { Pressure } \\
\text { (Torr) }\end{array}$ & $\begin{array}{c}\text { Time } \\
\text { (min) }\end{array}$ & $\begin{array}{c}\text { Exposure } \\
\text { (L) }\end{array}$ \\
\hline $\mathbf{1}$ & $1 \times 10^{7}$ & 1 & 6 \\
\hline $\mathbf{2}$ & $1 \times 10^{5}$ & 1 & 606 \\
\hline $\mathbf{3}$ & $2 \times 10^{4}$ & 1 & $1.3 \times 10^{4}$ \\
\hline $\mathbf{4}$ & $2 \times 10^{4}$ & 1 & $2.5 \times 10^{4}$ \\
\hline $\mathbf{5}$ & $2 \times 10^{4}$ & 1 & $3.7 \times 10^{4}$ \\
\hline $\mathbf{6}$ & $2 \times 10^{4}$ & 3 & $7.3 \times 10^{4}$ \\
\hline $\mathbf{7}$ & $2 \times 10^{4}$ & 3 & $1.1 \times 10^{5}$ \\
\hline $\mathbf{8}$ & $2 \times 10^{4}$ & 1 & $1.2 \times 10^{5}$ \\
\hline $\mathbf{9}$ & $2 \times 10^{4}$ & 1 & $1.3 \times 10^{5}$ \\
\hline $\mathbf{1 0}$ & $2 \times 10^{4}$ & 5 & $1.9 \times 10^{5}$ \\
\hline $\mathbf{1 1}$ & $2 \times 10^{4}$ & 5 & $2.5 \times 10^{5}$ \\
\hline $\mathbf{1 2}$ & $2 \times 10^{4}$ & 10 & $3.7 \times 10^{5}$ \\
\hline $\mathbf{1 3}$ & $2 \times 10^{4}$ & 10 & $4.9 \times 10^{5}$ \\
\hline
\end{tabular}

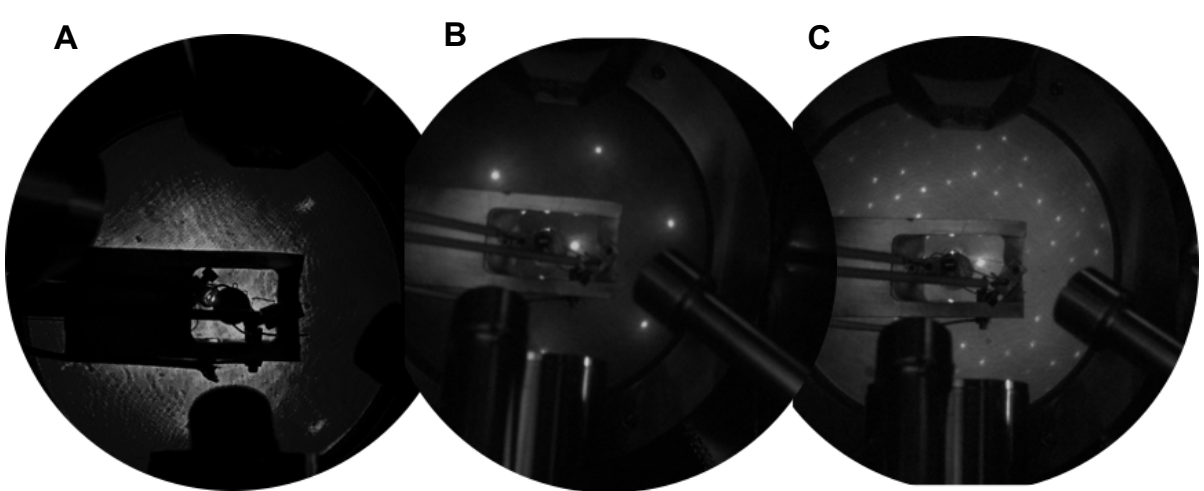

Figure S5. Low energy electron diffraction (LEED) data demonstrate that a disordered surface forms after oxidation of $\mathrm{Pd} / \mathrm{Ag}(111)$ in 2 Torr of $\mathrm{O}_{2}$ at $500 \mathrm{~K}$ for 5 minutes based (A) the diffuse background with only a faint $(1 \mathrm{x} 1)$ pattern following oxidation. For comparison, well-defined LEED patterns are observed for (B) clean $\mathrm{Ag}(111)$ and (C) for the $\mathrm{p}(4 \times 4)$-O layer formed after dosing $50 \mathrm{~L}$ of $\mathrm{NO}_{2}$ at $500 \mathrm{~K}$. All data were acquired at $61 \mathrm{eV}$ electron energy and at $300-320 \mathrm{~K}$ in UHV. 
Table S4. The rates of Ag oxide and Pd oxide reduction are estimated in three characteristic reduction regimes $(6 \times$ $10^{3}-3 \times 10^{4} \mathrm{~L}, 6 \times 10^{4}-1 \times 10^{5} \mathrm{~L}$, and $1 \times 10^{5}-3 \times 10^{5} \mathrm{~L}$ ) and plotted as a function of the cycle number.

\begin{tabular}{l|ccc|cc}
\hline & \multicolumn{3}{|c|}{ Ag oxide reduction rate } & \multicolumn{2}{c}{ Pd oxide reduction rate } \\
\hline & $\begin{array}{c}\text { 1st reduction } \\
\text { regime }\end{array}$ & $\begin{array}{c}\text { 2nd reduction } \\
\text { regime }\end{array}$ & $\begin{array}{c}\text { 3rd reduction } \\
\text { regime }\end{array}$ & $\begin{array}{c}\text { Induction } \\
\text { period }\end{array}$ & $\begin{array}{c}\text { Main } \\
\text { reduction } \\
\text { regime }\end{array}$ \\
\hline 1st cycle & 39.12 & 3.95 & 1.97 & 31.56 & 68.70 \\
\hline 2nd cycle & 29.38 & 2.85 & 1.41 & 16.93 & 44.08 \\
\hline 3rd cycle & 16.13 & 2.73 & 0.95 & 13.26 & 34.25 \\
\hline 4th cycle & 18.70 & 3.06 & 0.97 & 7.84 & 30.92 \\
\hline 5th cycle & 18.92 & 3.39 & 1.21 & 6.61 & 28.21 \\
\hline
\end{tabular}
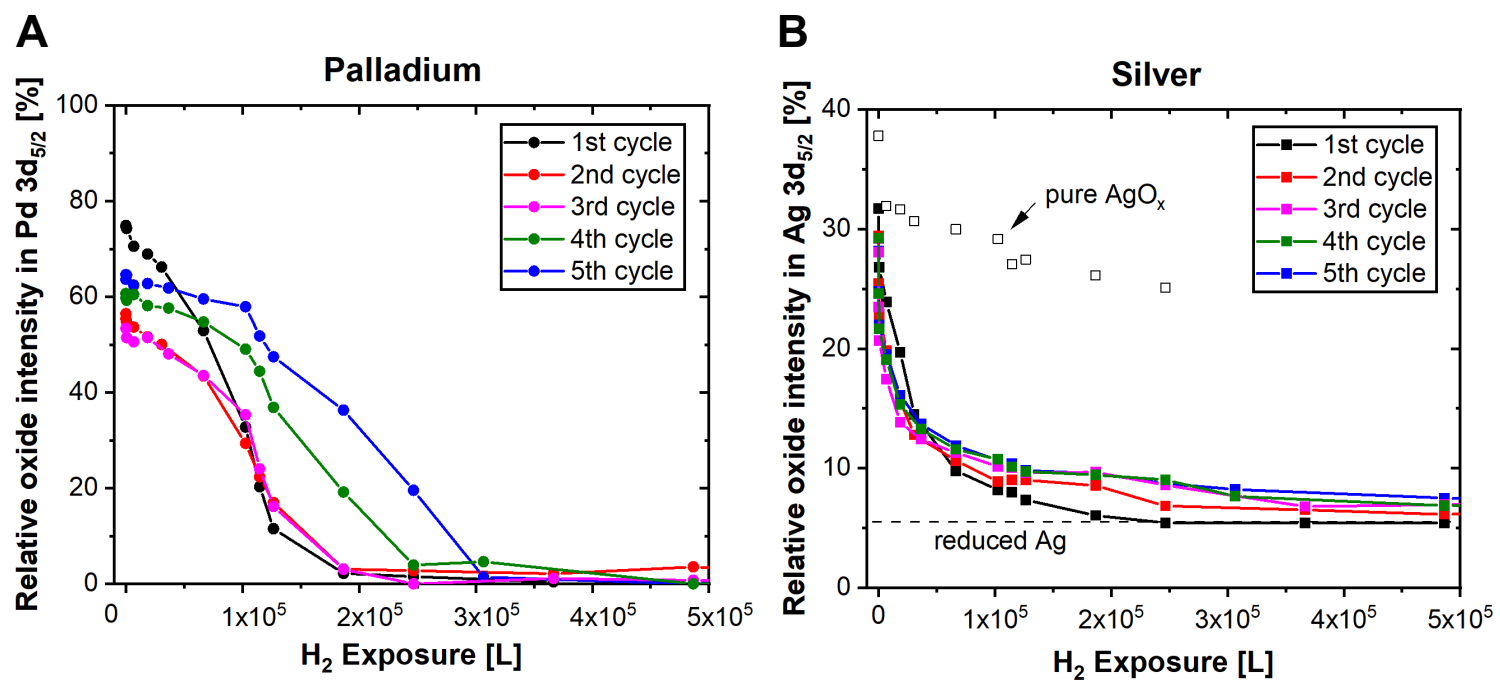

Figure S6. The relative amounts of oxidized Pd (A) and oxidized Ag (B) are measured as a function of the integrated $\mathrm{H}_{2}$ exposure for all consecutive cycles of oxidation and reduction in the $\mathrm{Ag} 3 \mathrm{~d}_{5 / 2}$ and $\mathrm{Pd} 3 \mathrm{~d}_{5 / 2}$ binding energy region, respectively. In all cases, oxidation was performed at $550 \mathrm{~K}$ using 2 Torr of $\mathrm{O}_{2}$ for 5 minutes. Molecular hydrogen was exposed to the surface at $300 \mathrm{~K}$ (Table S4) and spectra were obtained in UHV.

Table S5. The amount of $\mathrm{H}_{2}$ exposure for which the reduction rate of Pd oxide is slow for the various numbers of oxidation/reduction cycles.

\begin{tabular}{l|l}
\hline & Exposure of $\mathbf{H}_{2}$ before fast reduction of Pd oxide (L) \\
\hline Pd deposition & N/A \\
\hline $\mathbf{1}^{\text {st }}$ cycle & $3.1 \times 10^{4}$ \\
\hline $\mathbf{2}^{\text {nd }}$ cycle & $6.7 \times 10^{4}$ \\
\hline $\mathbf{3}^{\text {rd }}$ cycle & $1.0 \times 10^{5}$ \\
\hline $\mathbf{4}^{\text {th }}$ cycle & $1.0 \times 10^{5}$ \\
\hline $\mathbf{5}^{\text {th }}$ cycle & $1.0 \times 10^{5}$ \\
\hline
\end{tabular}




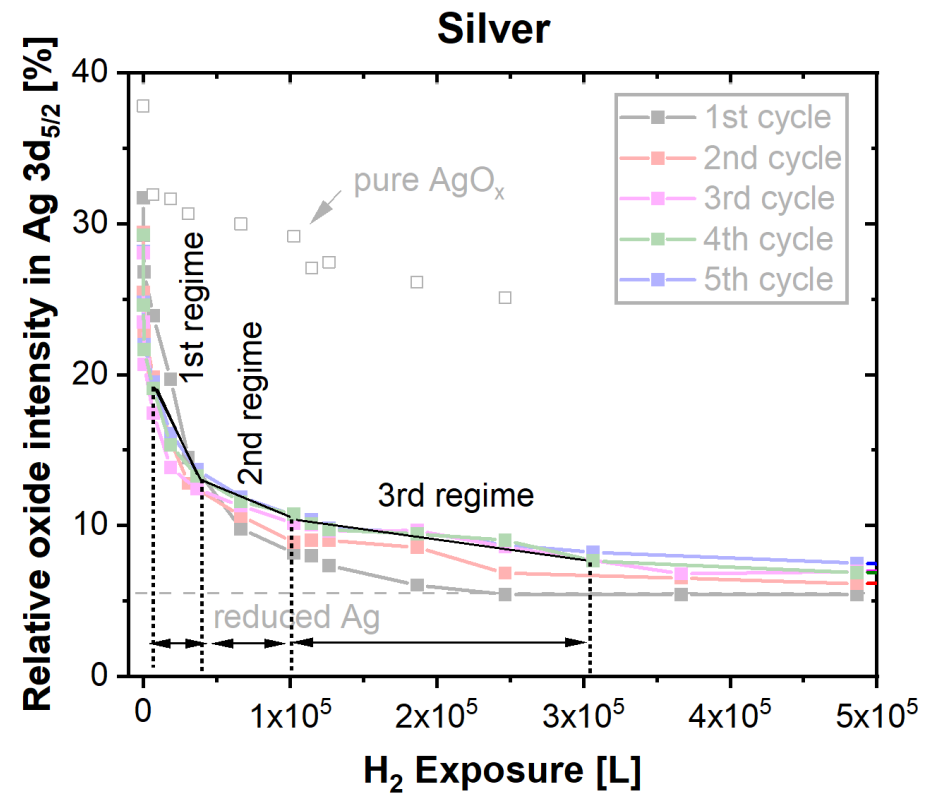

Figure S7. Example of the extraction of reduction rates in the three reduction regimes for Ag oxide approximated by a linear function. The reduction regimes are indicated in the graph and are $6 \times 10^{3}-3 \times 10^{4} \mathrm{~L}, 6 \times 10^{4}-1 \times 10^{5} \mathrm{~L}$, and $1 \times 10^{5}-3 \times 10^{5} \mathrm{~L}$ for the first, second and third regime, respectively.

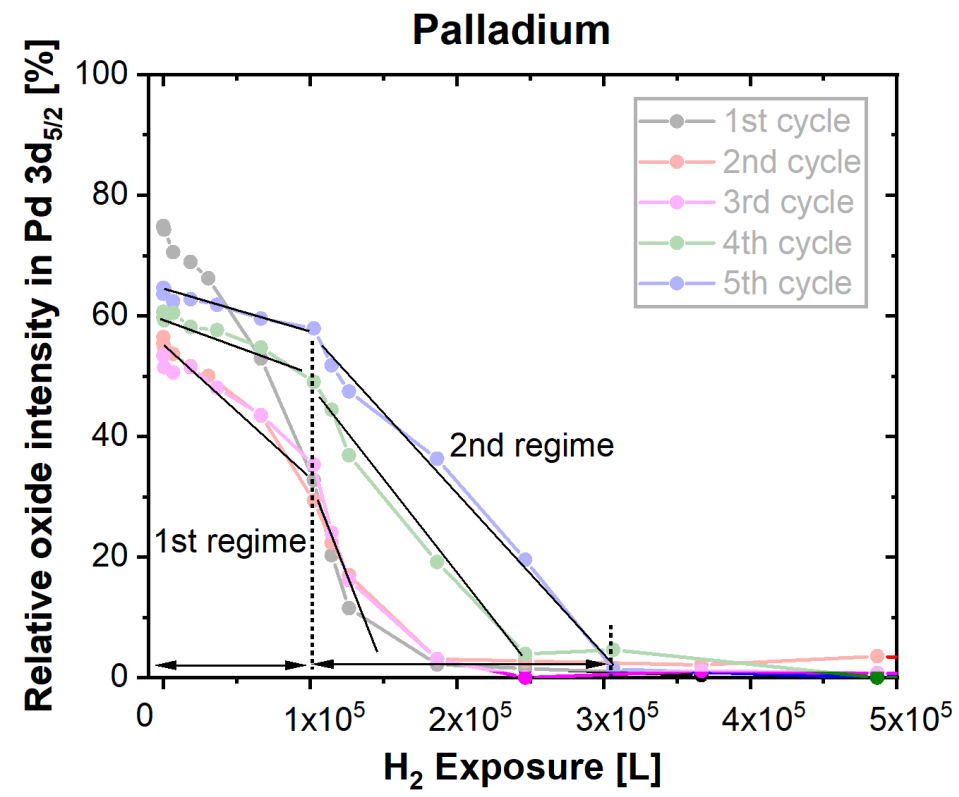

Figure S8. Example of the extraction of reduction rates in the three reduction regimes for Pd oxide approximated by a linear function. The reduction regimes are indicated in the graph. The $1^{\text {st }}$ regime (induction regime) is described in Table S3. The second, fourth and fifth cycle are visually highlighted. 


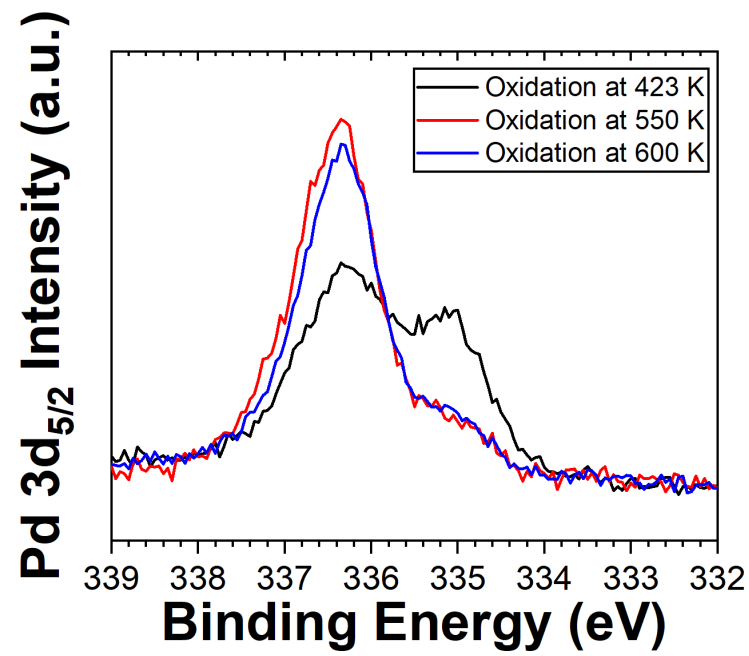

Figure S9. Pd oxide on $\mathrm{Ag}(111)$ is stable up to at least $600 \mathrm{~K}$ under 1 Torr of oxygen. The Pd $3 \mathrm{~d}_{5 / 2}$ binding energy region for oxidation in 2 torr of oxygen at $423 \mathrm{~K}$ (black), $550 \mathrm{~K}$ (red), $600 \mathrm{~K}$ (blue).

Table S6. Integrated intensity of $\mathrm{Pd}$ oxide contribution in $\mathrm{Pd} 3 \mathrm{~d}_{5 / 2}$ binding energy region.

\begin{tabular}{l|l|l}
\hline & $\begin{array}{l}\text { PdOx } \\
\text { intensity } \\
{[\mathbf{C P S} \text { eV] }}\end{array}$ & $\begin{array}{l}\text { Total Pd } \\
\text { intensity } \\
{[\mathbf{C P S} \text { eV] }}\end{array}$ \\
\hline Pd deposition & $\mathrm{N} / \mathrm{A}$ & 1336 \\
\hline $\mathbf{1}^{\text {st }}$ cycle & 864 & 1156 \\
\hline $\mathbf{2}^{\text {nd }}$ cycle & 499 & 884 \\
\hline $\mathbf{3}^{\text {rd }}$ cycle & 409 & 768 \\
\hline $\mathbf{4}^{\text {th }}$ cycle & 451 & 763 \\
\hline $\mathbf{5}^{\text {th }}$ cycle & 476 & 722 \\
\hline
\end{tabular}

\section{References}

(1) Martin, N. M.; Van Den Bossche, M.; Grönbeck, H.; Hakanoglu, C.; Zhang, F.; Li, T.; Gustafson, J.; Weaver, J. F.; Lundgren, E. CO Adsorption on Clean and Oxidized Pd(111). J. Phys. Chem. C 2014, 118, 1118-1128.

(2) Ketteler, G.; Ogletree, D. F.; Bluhm, H.; Liu, H.; Hebenstreit, E. L. D.; Salmeron, M. In Situ Spectroscopic Study of the Oxidation and Reduction of Pd(111). J. Am. Chem. Soc. 2005, 127, 18269-18273.

(3) Toyoshima, R.; Yoshida, M.; Monya, Y.; Kousa, Y.; Suzuki, K.; Abe, H.; Mun, B. S.; 
Mase, K.; Amemiya, K.; Kondoh, H. In Situ Ambient Pressure XPS Study of CO Oxidation Reaction on Pd(111) Surfaces. J. Phys. Chem. C 2012, 116, 18691-18697.

(4) Lundgren, E.; Kresse, G.; Klein, C.; Borg, M.; Andersen, J. N.; De Santis, M.; Gauthier, Y.; Konvicka, C.; Schmid, M.; Varga, P. Two-Dimensional Oxide on Pd(111). Phys. Rev. Lett. 2002, 88, 2461031-2461034.

(5) Van Den Bossche, M.; Martin, N. M.; Gustafson, J.; Hakanoglu, C.; Weaver, J. F.; Lundgren, E.; Grönbeck, H. Effects of Non-Local Exchange on Core Level Shifts for GasPhase and Adsorbed Molecules. J. Chem. Phys. 2014, 141, 034706.

(6) Martin, N. M.; Van Den Bossche, M.; Grönbeck, H.; Hakanoglu, C.; Gustafson, J.; Blomberg, S.; Arman, M. A.; Antony, A.; Rai, R.; Asthagiri, A.; Weaver, J. F.; Lundgren, E. Dissociative Adsorption of Hydrogen on PdO(101) Studied by HRCLS and DFT. $J$. Phys. Chem. C 2013, 117, 13510-13519.

(7) Heine, C.; Eren, B.; Lechner, B. A. J.; Salmeron, M. A Study of the O/Ag(111) System with Scanning Tunneling Microscopy and X-Ray Photoelectron Spectroscopy at Ambient Pressures. Surf. Sci. 2016, 652, 51-57.

(8) Zemlyanov, D. Y.; Savinova, E.; Scheybal, A.; Doblhofer, K.; Schlögl, R. XPS Observation of OH Groups Incorporated in an $\mathrm{Ag}(111)$ Electrode. Surf. Sci. 1998, 418, 441-456.

(9) Knudsen, J.; Martin, N. M.; Grånäs, E.; Blomberg, S.; Gustafson, J.; Andersen, J. N.; Lundgren, E.; Klacar, S.; Hellman, A.; Grönbeck, H. Carbonate Formation on p(4×4)O/Ag(111). Phys. Rev. B - Condens. Matter Mater. Phys. 2011, 84, 1-6.

(10) Rocha, T. C. R.; Oestereich, A.; Demidov, D. V.; Hävecker, M.; Zafeiratos, S.; Weinberg, G.; Bukhtiyarov, V. I.; Knop-Gericke, A.; Schlögl, R. The Silver-Oxygen System in Catalysis: New Insights by near Ambient Pressure X-Ray Photoelectron Spectroscopy. Phys. Chem. Chem. Phys. 2012, 14, 4554-4564.

(11) Isegawa, K.; Ueda, K.; Hiwasa, S.; Amemiya, K.; Mase, K.; Kondoh, H. Formation of Carbonate on $\operatorname{Ag}(111)$ under Exposure to Ethylene and Oxygen Gases Evidenced by near Ambient Pressure XPS and NEXAFS. Chem. Lett. 2019, 48, 159-162.

(12) Schnadt, J.; Knudsen, J.; Hu, X. L.; Michaelides, A.; Vang, R. T.; Reuter, K.; Li, Z.; Lægsgaard, E.; Scheffler, M.; Besenbacher, F. Experimental and Theoretical Study of Oxygen Adsorption Structures on Ag(111). Phys. Rev. B - Condens. Matter Mater. Phys. 
2009, $80,1-10$.

(13) Bukhtiyarov, V. I.; Hävecker, M.; Kaichev, V. V.; Knop-Gericke, A.; Mayer, R. W.; Schlögl, R. Atomic Oxygen Species on Silver: Photoelectron Spectroscopy and X-Ray Absorption Studies. Phys. Rev. B - Condens. Matter Mater. Phys. 2003, 67, 235422123542212 .

(14) Shinotsuka, H.; Tanuma, S.; Powell, C. J.; Penn, D. R. Calculations of Electron Inelastic Mean Free Paths. X. Data for 41 Elemental Solids over the $50 \mathrm{eV}$ to $200 \mathrm{keV}$ Range with the Relativistic Full Penn Algorithm. Surf. Interface Anal. 2015, 47, 871-888.

(15) Van Spronsen, M. A.; Daunmu, K.; O’Connor, C. R.; Egle, T.; Kersell, H.; OliverMeseguer, J.; Salmeron, M. B.; Madix, R. J.; Sautet, P.; Friend, C. M. Dynamics of Surface Alloys: Rearrangement of $\mathrm{Pd} / \mathrm{Ag}(111)$ Induced by $\mathrm{CO}$ and $\mathrm{O}_{2}$. J. Phys. Chem. C 2019, 123, 8312-8323.

(16) O’Connor, C. R.; van Spronsen, M. A.; Egle, T.; Xu, F.; Kersell, H. R.; Oliver-Meseguer, J.; Karatok, M.; Salmeron, M.; Madix, R. J.; Friend, C. M. Hydrogen Migration at Restructuring Palladium-Silver Oxide Boundaries Dramatically Enhances Reduction Rate of Silver Oxide. Nat. Commun. 2020, 11, 1844. 